\title{
KEJADIAN PENYAKIT CHIKUNGUNYA DI WILAYAH KERJA PUSKESMAS KECAMATAN MAKASAR JAKARTA TIMUR
}

\author{
Petrus Geroda Beda Ama
}

\author{
Program studi S1 Kesehatan Masyarakat Universitas MH.Thamrin \\ petrusgeroda@gmail.com
}

\begin{abstract}
ABSTRAK
Chikungunya adalah suatu jenis penyakit menular yang disebabkan oleh virus Chikungunya (CHIK). Tujuan penelitian ini adalah "Diketahuinya faktor apa sajakah yang berhubungan dengan kejadian Penyakit Chikungunya di wilayah kerja Puskesmas Kecamatan Makasar Jakarta Timur". Hasil penelitian analisis bivariate ditemukan ada dua variabel yang berhubungan dengan kejadian Penyakit Chikungunya yaitu : (1) Keberadaan jentik nyamuk : OR=2,062 dengan CI=1,1693,636, (2) Umur : $\mathrm{OR}=1,807$ dengan $\mathrm{CI}=1,117-2,923$. Sementara variabel jenis kelamin dan pekerjaan tidak berhubungan. Hasil analisa multivariate, variabel yang berhubungan dengan Chikungunya adalah keberadaan jentik nyamuk dan umur. keberadaan jentik nyamuk merupakan variabel yang paling dominan dengan nilai OR tertingi yaitu 2,286. Sementara Umur dengan nilai OR: 1,804. Namun menurut hubungan temporal, Keberadaan jentik tidak selalu mendahului kejadian Chikungunya, sementara umur selalu mendahului kejadian Chikungunya. Oleh karena itu, walaupun secara statistic, nilai OR tertinggi pada keberadaan jentik nyamuk namun secara temporal, Umur lebih dominan. Untuk menghindari resiko terjadinya penyakit Chikungunya maka pihak puskesmas perlu melakukan edukasi ke masyarakat terkait "Self Jumantik" untuk menekan keberadaan nyamuk maupun jentik nyamuk di lingkungan rumah warga.

Daftar Pustaka : 12 (2007-2015)
\end{abstract}

Kata Kunci: Kejadian Penyakit Chikungunya

\section{PENDAHULUAN}

Chikungunya adalah suatu jenis penyakit menular yang disebabkan oleh virus Chikungunya (CHIK) yaitu yang termasuk dalam famili Togaviridae, genus Alphavirus. Penyebaran CHIK dapat ditularkan melalui gigitan nyamuk Aedes aegypti (the yellow fever mosquito) dan Aedes albopictus (the Asian tiger mosquito) yang merupakan vektor potensial penyebaran Penyakit Chikungunya. (Depkes, 2007). Penyakit Chikungunya ini masih menjadi permasalahan kesehatan masyarakat sampai dengan saat ini. (Ditjen P2 PL, 2015)

Dari sejarah diduga KLB Chikungunya pernah terjadi pada tahun 1779 di Batavia dan Kairo; 1823 di Zanzibar; 1824 di India; 1870 di Zanzibar; 1871 di India; 1901 di Hongkong, Burma, dan Madras; 1923 di Calcuta. Dari tahun 1952 sampai kini virus telah tersebar luas di daerah Afrika dan menyebar ke Amerika dan Asia. Virus Chikungun menjadi endemis di wilayah Asia Tenggara sejak tahun 1954. Pada akhir tahun 1950 dan 1960 virus berkembang di Thailand, Kamboja, Vietnam, Manila dan Burma. Tahun 1965 terjadi KLB di Srilanka. (Kemenkes RI, 2012)

Di Indonesia, KLB penyakit Chikungunya pertama kali dilaporkan dan tercatat pada tahun 1973 terjadi di Samarinda Provinsi Kalimantan Timur dan di DKI Jakarta, Tahun 1982 di Kuala Tungkal Provinsi Jambi dan tahun 1983 di Daerah Istimewa Yogyakarta. KLB Chikungunya mulai banyak dilaporkan sejak tahun 1999 yaitu di Muara Enim (1999), Aceh (2000) Jawa Barat (Bogor, Bekasi, Depok) pada tahun 2001. (Ditjen P2 PL, 2015)

Hasil SDKI tahun 2012, dilaporkan bahwa jumlah kasus Chikungunya di Indonesia sebanyak 1.831 kasus. Jumlah ini menurun dibandingkan dengan 3 tahun sebelumnya yaitu pada tahun 2011 sebanyak 2.998, tahun 2010 sebanyak 52.703 kasus dan tahun 2009 sebanyak 83.756 kasus. (Kemenkes RI, 2013)

Propinsi DKI Jakarta adalah salah satu propinsi yang pernah melaporkan KLB penyakit Chikungunya pada tahun 2002 lalu. Sementara menurut data dari Survailens Sudinkes DKI Jakarta, bahwa pada tahun 2012, ditemukan 
sebanyak 36 kasus Chikungunya, tahun 2013 sebanyak 738 kasus Chikungunya dan tahun 2014 sebanyak 102 kasus Chikungunya. (Sudinkes DKI, 2015)

Berdasarkan data dari Sub Dinas Kesehatan Jakarta Timur, bahwa pada tahun 2012 sebanyak 14 kasus yang dilaporkan, tahun 2013 meningkat drastis yaitu sebanyak 566 yang dilaporkan. Sementara tahun 2014, laporan yang masuk hanya sebanyak 34 kasus. (Sudinkes DKI, 2015)

Puskesmas Kecamatan Makasar adalah salah satu puskesmas yang berada di Kecamatan Makasar Jakarta Timur. Adapun jumlah kasus kejadian Chikungunya di wilayah kerja Puskesmas Kec. Makasar pada tahun 2012 sebanyak 26 kasus, tahun 2013 sebanyak 246 kasus dan tahun 2014 sebanyak 125 kasus. (Puskesmas Kec. Makasar, 2015). Dari data ini dapat dilihat kejadian penyakit Chikungunya hampir setiap tahun selalu ada sehingga menjadi menarik untuk diteliti. Berdasarkan hasil studi pendahuluan didapatkan bahwa adanya kejadian Chikungunya ini dikarenakan perilaku masyarakat yang tidak menghindari resiko terjangkitnya penyakit ini. Disisi lain karakteristik responden juga mempunyai pengaruh yang sangat besar terhadap kejadian penyakit ini. Oleh karena ini maka perlu dilakukan penelitian untuk mengetahui faktor apa saja yang berpengaruh terhadap kejadian Penyakit Chikungunya di wilayah kerja Puskesmas Kecamatan Makasar Jakarta Timur"

\section{METODE}

Penelitian ini merupakan studi observasional (pengamatan) dengan jenis disain studi kasus control. Kasus adalah orang yang dengan gejala klinis dan laboratorium positif Chikungunya yang sudah didiagnosis oleh pelayanan kesehatan tahun 2014 di Puskesmas Kec. Makasar. Sementara Kontrol adalah orang yang benar-benar tidak menderita Chikungunya. Populasi dalam penelitian ini adalah semua penduduk di wilayah Puskesmas Kec. Makasar Jakarta Timur. Sementara sampel dari penelitian ini adalah terdiri atas Kasus dan Kontrol. Hasil perhitungan sampel menggunakan rumus Lameshow, 1991 diperoleh sampel sebesar 135 orang. Dengan perbandingan 1:1 maka diperoleh jumlah sampel untuk kasus dan kontrol sebesar 270 responden. Pengumpulan data mengunakan kuesioner. Pengolahan data dilakukan dengan bantuan aplikasi perangkat lunak computer. Sementara analisa data yang dilakukan adalah Analisa Univariat, Bivariat dan Multivariat.

Untuk mengetahui apakah hipotesis (H0) yang diajukan sebelumnya ditolak atau diterima, maka dilakukan uji statistik dengan ketentuan, bila $\mathrm{p}$ value $\leq \alpha(0,05)$ maka $\mathrm{H} 0$ ditolak, artinya ada perbedaan yang bermakna, bila $\mathrm{p}$ value $>\alpha(0,05)$ maka, H0 diterima, artinya tidak ada perbedaan yang bermakna (Hastono, 2007).

Besarnya resiko kejadian diukur dengan menggunakan Odds Rasio (OR). Ketentuannya adalah, jika nilai OR = 1, estimasi bahwa tidak ada pengaruh antara faktor resiko dengan kasus. Jika OR $>1$, Estimasi bahwa ada pengaruh positif antara faktor resiko dengan kasus. Dan jika OR < 1, estimasi bahwa ada hubungan negatif antara faktor resiko. (Lapau, 2014)

\section{HASIL}

\section{Hasil Univariat}

Hasil penelitian memperlihatkan banhwa antara kasus dan control perbandingannya sama yaitu 1:1 atau 143: 143 , Sementara pada variabel keberadaan jentik nyamuk prsesentase terbanyak pada keberadaan jentik negative yaitu 76,9\%. Pada variabel umur, presentase terbanyak terdapat pada kelompok umur $>35$ tahun yaitu $60,8 \%$. Pada variabel jenis kelamin, presentase terbanyak adalah pada jenis kelamin perempuan yaitu 59,1\%, sementar 
pada variabel pekerjaan, presentase terbanyak adalah pada kelompok yang tidak bekerja yaitu $65,7 \%$. Untuk lebih jelas dapat di lihat pada Tabel 1 .

Tabel 1.

Distribusi Dan Proporsi Hasil Penelitian Menurut Variabel Independen Dan Dependen

\begin{tabular}{|c|c|c|c|c|}
\hline No & Variabel & Kategori & Jumlah & Presentasi \\
\hline \multirow{3}{*}{1} & \multirow{3}{*}{$\begin{array}{l}\text { Kejadian Penyakit } \\
\text { Chikungunya }\end{array}$} & Kasus & 143 & 50,0 \\
\hline & & Kontrol & 143 & 50,0 \\
\hline & & Total & 286 & 100,0 \\
\hline \multirow{3}{*}{2} & \multirow{3}{*}{ Keberadaan Jentik Nyamuk } & Positif & 66 & 23,1 \\
\hline & & Negatif & 220 & 76,9 \\
\hline & & Total & 286 & 100,0 \\
\hline \multirow{3}{*}{3} & \multirow{3}{*}{ Umur } & $\leq 35$ tahun & 112 & 39,2 \\
\hline & & $>35$ Tahun & 174 & 60,8 \\
\hline & & Total & 286 & 100,0 \\
\hline \multirow{3}{*}{4} & \multirow{3}{*}{ Jenis Kelamin } & Laki-Laki & 117 & 40,9 \\
\hline & & Perempuan & 169 & 59,1 \\
\hline & & Total & 286 & 100,0 \\
\hline \multirow[t]{3}{*}{5} & \multirow[t]{3}{*}{ Pekerjaan } & Bekerja & 98 & 34,3 \\
\hline & & Tidak Bekerja & 188 & 65,7 \\
\hline & & Total & 286 & 100,0 \\
\hline
\end{tabular}

\section{Hasil Bivariat}

Dalam analisis Bivariat ini peneliti menggunakan uji Chi-Square oleh karena semua variabel berbentuk kategorik dengan masing-masing 2 kelompok kategori. Hasil uji memperlihatkan ada dua variabel yang berhubungan dengan kejadian Chikungunya yaitu :

1. Keberadaan jentik nyamuk. Nilai OR yang diperoleh sebesar 2,062 dengan $C I=1,169-3,636$, artinya, responden yang di rumahnya terdapat jentik positif mempunyai resiko 2 kali menderita penyakit Chikungunya dibandingkan dengan responden yang di rumahnya terdapat jentik negatif.

2. Umur. Nilai OR yang diperoleh sebesar 1,807 dengan $\mathrm{CI}=1,117-2,923$ yang artinya, responden yang berumur $\leq 35$ tahun memiliki peluang 2 kali menderita penyakit Chikungunya dibandingkan dengan responden yang responden yang berumur $>35$

Sementara 2 variabel lain tidak berhubungan dengan kejadian Chikungunya yaitu Jenis Kelamin dan Pekerjaan karena masing-masing mempunyai nilai $\mathrm{p}>$ dari alpha 0,05 dan nilai $\mathrm{OR}<1$. Untuk lebih jelas, hasil Bivariat dapat di lihat pada Tabel 2 berikut. 
Tabel 2.

Distribusi Hubungan Antara Variabel Independen Dan Dependen Menurut Analisis Bivariat

\begin{tabular}{|c|c|c|c|c|c|c|c|c|c|}
\hline \multirow[t]{2}{*}{ Variabel } & \multirow[t]{2}{*}{ Kategori } & \multicolumn{6}{|c|}{ Kejadian Penyakit Cikungunya } & \multirow[t]{2}{*}{$\begin{array}{c}\mathrm{P} \\
\text { Value }\end{array}$} & \multirow[t]{2}{*}{$\begin{array}{c}\text { OR } \\
95 \% \mathrm{Cl}\end{array}$} \\
\hline & & Kasus & $\%$ & Kontrol & $\%$ & Total & $\%$ & & \\
\hline \multirow{2}{*}{$\begin{array}{l}\text { Keberadaan Jentik } \\
\text { Nyamuk }\end{array}$} & Positif & 42 & 29,4 & 24 & 16,8 & 66 & 23,1 & \multirow{3}{*}{0,017} & \multirow{3}{*}{$\begin{array}{c}2,062 \\
1,169-3,636\end{array}$} \\
\hline & Negatif & 101 & 70,6 & 119 & 83,2 & 220 & 76,9 & & \\
\hline \multicolumn{2}{|l|}{ Total } & 143 & 100,0 & 143 & 100,0 & 286 & 100,0 & & \\
\hline \multirow[t]{2}{*}{ Umur } & $\leq 35$ tahun & 66 & 46,2 & 46 & 32,2 & 112 & 39,2 & \multirow{3}{*}{0,021} & \multirow{3}{*}{$\begin{array}{c}1,807 \\
1,117-2,923\end{array}$} \\
\hline & $>35$ tahun & 77 & 53,8 & 97 & 67,8 & 174 & 60,8 & & \\
\hline \multicolumn{2}{|l|}{ Total } & 143 & 100,0 & 143 & 100,0 & 286 & 100,0 & & \\
\hline \multirow[t]{2}{*}{ Jenis Kelamin } & Laki-Laki & 52 & 36,4 & 65 & 45,5 & 117 & 40,9 & \multirow{3}{*}{0,149} & \multirow{3}{*}{$\begin{array}{c}0,686 \\
0,427-1,101\end{array}$} \\
\hline & Perempuan & 91 & 63,6 & 78 & 54,5 & 169 & 59,1 & & \\
\hline \multicolumn{2}{|l|}{ Total } & 143 & 100,0 & 143 & 100,0 & 286 & 100,0 & & \\
\hline \multirow[b]{2}{*}{ Pekerjaan } & Bekerja & 68 & 47,6 & 84 & 58,7 & 152 & 53,1 & \multirow{3}{*}{0,075} & \multirow{3}{*}{$\begin{array}{c}0,637 \\
0,399-1,016\end{array}$} \\
\hline & Tidak Bekerja & 75 & 52,4 & 59 & 41,3 & 134 & 46,9 & & \\
\hline Total & & 143 & 100,0 & 143 & 100,0 & 286 & 100,0 & & \\
\hline
\end{tabular}

\section{Hasil Multivariat}

\section{Seleksi Bivariat}

Analisis Multivariat ini dimulai dengan seleksi Bivariat, dengan standar nilai alpha sebesar 0,25. Ketentuannya adalah, variabel dapat lolos seleksi dan ikut multivariat apabila nila $\mathrm{p}$ value yang dihasilkan $\leq$ alpha. Hasil seleksi Bivariat disajikan dalam tabel 3 berikut.

Tabel 3.

Seleksi Bivariat

\begin{tabular}{clcl}
\hline No & \multicolumn{1}{c}{ Variabel } & P Value & \multicolumn{1}{c}{ Keterangan } \\
\hline 1 & Keberadaan jentik & 0,011 & Ikut Multivariat \\
\hline 2 & Umur & 0,015 & Ikut Multivariat \\
\hline 3 & Jenis kelamin & 0,118 & Ikut Multivariat \\
\hline 4 & Pekerjaan & 0,058 & Ikut Multivariat \\
\hline
\end{tabular}

Hasil seleksi Bivariat didapatkan bahwa ke-empat variabel (keberadaan jentik nyamuk, umur, jenis kelamin, dan pekerjaan) menghasilkan nilai $\mathrm{P}$ value $<0,25$ sehingga ke-empat variabel tersebut diikutkan dalam pemodelan mutivariat. Langkah selanjutnya adalah melakukan pemodelan mutivariat.

\section{Pemodelan Multivariat}

Dalam Pemodelan Multivariat, Variabel yang lolos pemodelan jika nilai $\mathrm{P}$ value yang dihasilkan aplha $<0,05$. Jika ada nilai $\mathrm{P}>$ alpha 0,05 maka dikeluarkan satu persatu dari model, dimulai dengan nilai $\mathrm{p}$ value terbesar, kemudian dihitung perubahan nilai OR sebelum dan sesudah variabel tersebut dikeluarkan. Pemodelan pertama, disajikan dalam tabel 4. 
Tabel 4.

Pemodelan I Multivariat

\begin{tabular}{ccccc}
\hline No & Variabel & P Value & OR & (95\% CI) \\
\hline 1 & Keberadaan jentik & 0,006 & 2,286 & $(1,275-4,098)$ \\
\hline 2 & Umur & 0,020 & 1,804 & $(1,098-2,965)$ \\
\hline 3 & Jenis kelamin & 0,540 & 0,806 & $(0,404-0,1607)$ \\
\hline 4 & Pekerjaan & 0,424 & 0,757 & $(0,382-1,498)$ \\
\hline
\end{tabular}

Dari tabel deiatas terlihat ada 2 variabel yaitu jenis kelamin dan pekerjaan mempunyai nilai $\mathrm{P}>$ dari alpha $(0,05)$, dengan demikian maka variabel tersebut harus dikeluarkan dari model. Variabel pertama yang dikeluarkan adalah jenis kelamin.

Tabel 5.

Pemodelan II Multivariat Jenis Kelamin Dikeluarkan Dari Model

\begin{tabular}{cccc}
\hline No & Variabel & P Value & OR \\
\hline 1 & Keberadaan jentik & 0,006 & 2,256 \\
\hline 2 & Umur & 0,022 & 1,786 \\
\hline 3 & Pekerjaan & 0,082 & 0,651
\end{tabular}

Langkah selanjutnya adalah menghitung perubahan OR, dengan ketentuan jika setelah salah satu variabel dikeluarkan dari model dan ditemukan ada perubahan OR sebesar 10\% maka variabel tersebut dimaksukan kembali ke model, namun jika perubahan OR kurang dari 10\% maka variabel tersebut terus dikeluarkan dari model.

Tabel 6.

Perubahan OR Setelah Variabel Jenis Kelamin Dikeluarkan

\begin{tabular}{llccc}
\hline No & \multicolumn{1}{c}{ Variabel } & $\begin{array}{c}\text { OR ketika Jenis } \\
\text { Kelamin ada }\end{array}$ & $\begin{array}{c}\text { OR ketika Jenis } \\
\text { Kelamin tidak ada }\end{array}$ & $\begin{array}{c}\text { Perubahan } \\
\text { OR }(\%)\end{array}$ \\
\hline 1 & Keberadaan Jentik & 2,286 & 2,256 & $1,3 \%$ \\
\hline 2 & Umur & 1,804 & 1,786 & $1,9 \%$ \\
\hline 3 & Jenis Kelamin & 0,806 & - & - \\
\hline 4 & Pekerjaan & 0,757 & 0,651 & $14,0 \%$ \\
\hline
\end{tabular}

Hasil perhitungan perubahan OR ternyata setelah variabel jenis kelamin dikeluarkan, ada perubahan OR >10\%. Dengan demikian maka variabel jenis kelamin dimasukan kembali kedalam model. Langkah selanjutnya adalah mengeluarkan variabel pekerjaan, karena mempunyai nilai $\mathrm{p}$ value terbesar kedua setelah variabel Jenis kelamin.

Tabel 7.

Pemodelan III Multivariat Variabel Pekerjaan Dikeluarkan Dari Model

\begin{tabular}{llcc}
\hline No & \multicolumn{1}{c}{ Variabel } & $\begin{array}{c}\text { P } \\
\text { Value }\end{array}$ & OR \\
\hline 1 & Keberadaan jentik & 0,006 & 2,285 \\
\hline 2 & Umur & 0,014 & 1,858 \\
\hline 3 & Jenis Kelamin & 0,097 & 0,661 \\
\hline
\end{tabular}

Setelah variabel pekerjaan dikeluarkan, selanjutnya menghitung perubahan OR 
Tabel 8

Perubahan OR Setelah Variabel Pekerjaan Dikeluarkan

\begin{tabular}{llccc}
\hline No & \multicolumn{1}{c}{ Variabel } & $\begin{array}{c}\text { OR ketika Ada } \\
\text { pekerjaan }\end{array}$ & $\begin{array}{c}\text { OR ketika pekerjaan } \\
\text { tidak ada }\end{array}$ & $\begin{array}{c}\text { Perubahan } \\
\text { OR }(\%)\end{array}$ \\
\hline 1 & Keberadaan jentik & 2,286 & 2,285 & $0,04 \%$ \\
2 & Umur & 1,804 & 1,858 & $3,0 \%$ \\
3 & Jenis Kelamin & 0,806 & 0,661 & 18,0 \\
4 & Pekerjaan & 0,757 & - & - \\
\hline
\end{tabular}

Hasil perhitungan perubahan OR ternyata setelah variabel pekerjaan dikeluarkan, ada perubahan OR $>10 \%$. Dengan demikian maka variabel pekerjaan dimasukan kembali kedalam model. Langkah selanjutnya adalah mengeluarkan variabel lain yang mempunyai nilai $p$ value lebih besar dari alpha, namun terlihat sudah tidak ada lagi variabel yang dapat dikeluarkan dari model, dengan demikian maka pemodelan ini selesai. Selanjutntya adalah pemodelan terakhir dengan memasukan kembali variabel pekerjaan.

Tabel 9

Pemodelan Terakhir

\begin{tabular}{llccc}
\hline No & \multicolumn{1}{c}{ Variabel } & $\begin{array}{c}\text { P } \\
\text { Value }\end{array}$ & OR & $\mathbf{( 9 5 \% ~ C I )}$ \\
\hline 1 & Keberadaan Jentik & 0,006 & 2,286 & $(1,275-4098)$ \\
\hline 2 & Umur & 0,020 & 1,804 & $(1,098-2,965)$ \\
\hline 3 & Jenis Kelamin & 0,540 & 0,806 & $(0,404-1,607)$ \\
\hline 4 & Pekerjaan & 0,424 & 0,757 & $(0,382-1,498)$ \\
\hline
\end{tabular}

Berdasarkan analisa multivariate setelah melalui tiga tahap pemodelan ternyata variabel yang berhubungan dengan kejadian penyakit Chikungunya adalah keberadaan jentik nyamuk dan umur. Namun dari ke dua variabel tersebut ternyata variabel keberadaan jentik nyamuk merupakan variabel yang paling dominan berhubungan dengan kejadian Chikungunya, oleh karena mempunyai nilai OR tertingi yaitu 2,286. Dari hasil OR tersebut dapat disimpulkan bahwa responden yang dirumahnya terdapat jentik nyamuk positif mempunyai kecenderungan 2 kali beresiko menderita penyakit Chikungunya dibandingkan dengan responden yang di rumahnya terdapat jentik nyamuk negatif, setelah dikontrol variabel umur, jenis kelamin dan pekerjaan.

\section{PEMBAHASAN}

\section{Hubungan Sebab Akibat}

Atas dasar hasil analisis Multivariat ditemukan variabel independen yang berhubungan dengan kejadian Chikungunya adalah; keberadaan jentik nyamuk, dan umur. Untuk menentukan hubungan sebab akibat digunakan kriteria yaitu temporal, plausability, dose response relationship, kekuatan asosiasi konsistensi dan jenis desain (Kriteria Hill).

\section{Keberadaan Jentik Nyamuk}

Temporal ( \pm ): tidak diyakini bahwa keberadaan jentik nyamuk tidak selalu mendahului kejadian penyakit Chikungunya dengan asumsi bahwa bisa jadi penyakit Chikungunya itu sudah terjadi sebelum jentik itu ada.

Plausibility (+) Kepadatan jentik disuatu tempat sangat menentukan kejadian penyakit Chikungunya, hal ini dikarenakan jentik nyamuk tersebut pada masanya akan berubah menjadi nyamuk dewasa dan bila menggigit penderita Chikungunya pada akhirnya dapat menularkan virus Chikungunya kepada orang lain. 
Dose Response Relationship (-) : tidak dapat menentukan Dose Response Relationship karena data yang digunakan adalah kategorikal bukan data continouse.

Kekuatan Asosiasi (+) kekuatan hubungan antara keberadaan jentik nyamuk dengan kejadian penyakit Chikungunya yaitu OR=2,062 kali $(1,169-3,636)$ artinya responden yang di rumahnya terdapat jentik nyamuk positif beresiko 2,1 kali menderita penyakit Chikungunya dibandingakan dengan responden yang di rumahnya terdapat jentik nyamuk negatif.

Konsistensi (+): Hasil penelitian ini memiliki hubungan sejalan dengan penelitian yang dilakuakn oleh Diansari 2010, dimana kekuatan hubungan jentik dengan kejadian Chikungunya yaitu OR=5,375. Sejalan juga dengan penelitian Sitepu, Arasanti, \& Rambe, 2014, yang menemukan kekuatan hubungan antara keberadaan jentik nyamuk dengan kejadian penyakit Chikungunya yaitu $\mathrm{OR}=6,206 ; \mathrm{CI}=2,905-13,257$.

Jenis desain (-): Inferensi jenis desain studi kasus kontrol lemah yaitu moderately sugestive.

\section{Umur}

Temporal (+): diyakini bahwa umur mendahului kejadian penyakit Chikungunya.

Plausibility (+) Kejadian Penyakit Chikungunya pada seseorang tidak pernah memandang umur. Siapa saja bisa terserang penyakit ini, baik anak-anak maupun dewasa. Namun yang lebih beseriko sering kali pada umur $\leq 35$ tahun. Hal ini karena pada usia ini, seseorang sering aktif melakukan aktifitas pada siang hari, sementara nyamuk Aedes aegypti juga berperilaku menggigit pada waktu siang hari. Dengan demikian sehingga pada usia ini, sering menjadi sasaran gigit bagi nyamuk aedes aegipti yang dapat menularkan viris Chikungunya. Disisi lain, pada usia anak-anak juga sering mnjadi sasaran gigi nyamuk aedes aegipti ini, karena anak-anak cenderung duduk di dalam kelas selama pagi hingga siang hari dan kaki mereka yang tersembunyi di bawah meja menjadi sasaran empuk nyamuk jenis ini. Dengan demikian sehingga besar kemungkinan bagi nyamuk untuk dapat menyebarkan virus Chikungunya pada usia ini.

Dose Response Relationship (-) : tidak dapat menentukan Dose Response Relationship karena data yang digunakan adalah kategorikal bukan data continouse.

Kekuatan Asosiasi (+) Kekuatan hubungan antara umur dengan kejadian penyakit Chikungunya yaitu $\mathrm{OR}=1,807$ kali $(1,117-2,923)$ artinya responden yang berumur $\leq 35$ tahun beresiko 1,8 kali menderita penyakit Chikungunya dibandingakan dengan responden yang berumur $>35$.

Konsistensi (+): Hasil penelitian ini memiliki hubungan sejalan dengan penelitian yang dilakukan oleh Lulus \& Trapsilowat, 2014 yang dalam penelitiannya menyatakan ada hubungan antara umur dengan kejadian Chikungunya dimana pada alpha 5\% diperoleh p value sebesar 0,039. Sejalan juga dengan Sitepu, Arasanti, \& Rambe, 2014, yang juga menemukan bahwa ada hubungan antara terdapat jentik nyamuk di tempat penampungan air (TPA) sekitar rumah dengan kejadian Chikungunya ( $\mathrm{p}$-value=0,000; OR=6,206; CI= 2,905$13,257)$

Jenis desain (-): inferensi jenis desain studi kasus kontrol lemah yaitu moderately suggestive menunjukan bahwa variabel-variabel independen yang berhubungan sebab akibat dengan kejadian Chikungunya berturut turut menurut dominasinya adalah umur dan keberadaan jentik nyamuk. 


\section{Implikasi Hasil Penelitian}

\section{Umur Responden}

Umur berhubungan sebab akibat dengan kejadian penyakit Chikungunya. Umur yang $\leq 35$ tahun lebih beresiko 1,8 kali menderita penyakit Chikungunya dibandingkan dengan umur $>35$ tahun.

Rekomendasi:

Supaya jangan terjadi penyakit Chikungunya maka diusahakan agar memberikan perhatian khusus pada golongan umur $\leq 35$ Tahun.

Atas dasar rekomendasi diatas maka disarankan menggunakan pakayan yang dapat menutupi seluruh tubuh terutama tangan dan kaki pada waktu beraktivitas.Khusus bagi anak-anak sekolah yang menggunakan celana pendek, harus memakai kaus kaki yang bisa menutupi seluruh kakinya (diatas lutut)

\section{Keberadaan Jentik Nyamuk}

Keberadaan jentik nyamuk berhubungan sebab akibat dengan kejadian penyakit Chikungunya.

Keberadaan jentik nyamuk positif berpengaruh 2,1 kali menimbulkan kejadian penyakit Chikungunya dibandingkan dengan keberadaan jentik nyamuk negatif

Rekomendasi:

Supaya jangan terjadi penyakit Chikungunya maka diusahakan jangan ada jentik nyamuk positif dilingkungan manusia

Atas dasar rekomendasi diatas maka disarankanelakukan Pemberantasan Sarang Nyamuk (PSN) dengan 3 M

(Mengubur barang bekas, menguras dan menutup tempat penampungan air); Membasmi nyamuk dengan cara kimia maupun biologi.

\section{Variabel Independen Yang Tidak Berhubungan Dengan Kejadian Penyakit Chikungunya.}

\section{Jenis Kelamin}

Hasil penelitian ini menunjukan tidak ada hubungan sebab akibat antara jenis kelamin dengan kejadian Chikungunya. Walapun secara teori menyatakan bahwa jenis kelamin laki-laki lebih beresiko menderita penyakit chikungunmya dibandingkan dengan perempuan. Namun penelitian kali ini tidak sejalan dengan teori tersebut. Penelitian inipun mematahkan hasil penelitian Lulus Susanti, R.A. Yuniarti dan Wiwik Trapsilowati dalam jurnal kesehatan 2014, yang menemukan bahwa ada hubungan antara jenis kelamin dengan kejadian Chikungunya.

Menurut asumsi peneliti bahwa siapa saja dapat tergigit oleh nyamuk Aedes Aegypti dan menderita penyakit Chikungunya tanpa memandang jenis kelamin tertentu. Kecenderungan terjadi pada jenis kelamin tertentu itu merupakan faktor kebetulan.

\section{Pekerjaan}

Hasil penelitian ini menunjukan tidak ada hubungan sebab akibat antara pekerjaan dengan kejadian Chikungunya. Walaupun secara teori menyatakan orang yang bekerja lebih beresiko menderita penyakit Chikungunya, namun penelitian kali ini tidak sejalan dengan teori tersebut. Penelitian ini juga mematahkan hasil penelitian Lulus Susanti, R.A. Yuniarti dan Wiwik Trapsilowati dalam jurnal kesehatan 2014, yang menemukan 
bahwa ada hubungan antara Pekerjaan dengan kejadian Chikungunya. Tidak sejalan juga denganpenelitian Dyan Kunthi, 2011 yang juga menemukan bahwa ada hubungan antara Pekerjaan dengan kejadian Chikungunya dengan nilai $\mathrm{OR}=2,395 \% \mathrm{Ci}: 1,21-4,37$ dan $\mathrm{p}$ value $=0,016$.

Menurut asumsi peneliti bahwa baik yang bekerja maupun yang tidak bekerja, semuanya mempunyai resiko yang sama untuk menderita penyakit Chikungunya, hanya saja tergantung kepada kesempatan mereka untuk tergigit oleh nyamuk.

\section{DAFTAR PUSTAKA}

1. Depkes. (2007). Profil Kesehatan Indonesia 2006,. Jakarta: Depkes RI.

2. Diansari, R. (2010). Faktor Lingkungan Rumah Yang Mempengaruhi Kejadian Chikungunya Di Daerah Perkebunan Karet Kecamatan Lubuk Raja Kabupaten Oku Sumatera Selatan. Skripsi. Semarang: Universitas Diponegoro.

3. Ditjen P2 PL. (2015). Rencana Aksi Program PP dan PL 2015-2019. Jakarta: Ditjen P2 PL.

4. Hastono, P. S. (2007). Analisis Data Kesehatan. Depok: Fakultas Kesehatan Masyarakat Universitas Indonesia.

5. Kemenkes RI. (2012). Pedoman Pengendalian Demam Chlkungunya (2 ed.). Jakarta: Ditjen P2 PL.

6. Kemenkes RI. (2013). Pusat Data dan Informasi Profil Kesehatan Indonesia 2012. Jakarta: Kemenkes RI.

7. Kunthi, D. N., \& Taliah. (2011). Analisis Faktor Lingkungan Dan Sosiodemografi Dengan Terjadinya Demam Chikungunya Di Desa Sukasari Kecamatan Pameungpeuk Kabupaten Bandung. Jurnal Kesehatan Kartika, 79-80.

8. Lapau, B. (2014). Metodelogi Penelitian Kesehatan. Jakarta: Yayasan Pustaka Obor Indonesia.

9. Lulus, S. R., \& Trapsilowat, W. (2014). Faktor Risiko KejadianChikungunya Di Kabupaten Boyolal, Provinsi Jawa Tengah. Bul. Penelit. Kesehat, Vol. 42. No.1, 1-14.

10. Puskesmas Kec. Makasar. (2015). Laporan Survalian Epidemiologi. Jakarta: Puskesmas Kec.Makasar.

11. Sitepu, Y. F., Arasanti, E., \& Rambe, A. (2014, Juni). Faktor Risiko Kejadian Luar Biasa (KLB) Demam Chikungunya Di Kecamatan Batang Toru, Kabupaten Tapanuli Selatan Sumatera Utara Tahun 2014. Balaba Vol. 10 No. 01, 31-38.

12. Sudinkes DKI. (2015). Survailans Epidemiologi, Subdin Kesehatan Masyarakat. Dipetik Maret 12, 2015, dari Data tabular dari PWS KLB (W2) Kecamatan: http://surveilans-dinkesdki.net/ 